\title{
Cyclic AMP-Responsive Element-Binding Protein 3-Like Protein 3
}

National Cancer Institute

\section{Source}

National Cancer Institute. Cyclic AMP-Responsive Element-Binding Protein 3-Like Protein

3. NCI Thesaurus. Code C95487.

Cyclic AMP-responsive element-binding protein 3-like protein 3 (461 aa, $49 \mathrm{kDa}$ ) is encoded by the human CREB3L3 gene. This protein plays a role in the cellular response to endoplasmic reticulum stress. 